\title{
Extracelluláris vesiculák és hematológiai malignitásokban játszott szerepük
}

\author{
Rzepiel Andrea ${ }^{1}$ - Kutszegi Nóra ${ }^{1,2}$ - Cs. Sági Judit dr. ${ }^{2}$ \\ Kelemen Andrea $^{2}$ - Pálóczi Krisztina ${ }^{2}$ - F. Semsei Ágnes dr. ${ }^{2}$ \\ Buzás Edit dr. ${ }^{2}$. Erdélyi Dániel János dr. ${ }^{1}$
}

Semmelweis Egyetem, Általános Orvostudományi Kar, ${ }^{1}$ II. Gyermekgyógyászati Klinika,

${ }^{2}$ Genetikai, Sejt- és Immunbiológiai Intézet, Budapest

\begin{abstract}
Extracelluláris vesiculák minden szervezetben képződnek. Három legintenzívebben vizsgált csoportjuk az apoptotikus testek, a microvesiculák és az exosomák. A sejtek közötti kommunikációban, immunreakciókban, angiogenezisben betöltött szerepük csak néhány az eddig megismertek közül. A fiziológiás folyamatok mellett sokféle betegségben leírták változásaikat; a patomechanizmusban betöltött szerepük mellett felvetődik potenciális használatuk biomarkerekként. A szerzők betekintést kívánnak nyújtani az extracelluláris vesiculák kutatásába, kiemelve azt a néhány tanulmányt, amely a hematológiai malignitásokra fókuszált. A microvesiculák és exosomák vérplazmában mért mennyisége, a terápia során megfigyelt minőségi változása miatt felmerült, hogy a diagnosztikában, prognosztikában, illetve a minimális residualis betegség monitorozásában is használhatók lehetnek. Akut myeloid leukaemiában a természetes ölősejtek aktivitásának szupresszálásában bizonyított a blasteredetű exosomák szerepe. Krónikus lymphoid leukaemiában a microvesiculák közremúködése valószínû́ a gyógyszer-rezisztencia kialakulásában is. Orv. Hetil., 2016, 157(35), 1379-1384.
\end{abstract}

Kulcsszavak: biomarker, extracelluláris vesicula, exosoma, leukaemia, microvesicula/microparticula

\section{Extracellular vesicles and their role in hematological malignancies}

\begin{abstract}
Extracellular vesicles are produced in all organisms. The most intensively investigated categories of extracellular vesicles include apoptotic bodies, microvesicles and exosomes. Among a very wide range of areas, their role has been confirmed in intercellular communication, immune response and angiogenesis (in both physiological and pathological conditions). Their alterations suggest the potential use of them as biomarkers. In this paper the authors give an insight into the research of extracellular vesicles in general, and then focus on published findings in hematological malignancies. Quantitative and qualitative changes of microvesicles and exosomes may have value in diagnostics, prognostics and minimal residual disease monitoring of hematological malignancies. The function of extracellular vesicles in downregulation of natural killer cells' activity has been demonstrated in acute myeloid leukemia. In chronic lymphocytic leukemia, microvesicles seem to play a role in drug resistance.
\end{abstract}

Keywords: biomarker, extracellular vesicle, leukemia, exosome, microvesicle/microparticle

Rzepiel, A., Kutszegi, N., Cs. Sági, J., Kelemen, A., Pálóczi, K., F. Semsei, Á., Buzás, E., Erdélyi, D. J. [Extracellular vesicles and their role in hematological malignancies]. Orv. Hetil., 2016, 157(35), 1379-1384.

(Beérkezett: 2016. május 31.; elfogadva: 2016. június 23.)

\section{Rövidítések}

$\mathrm{AKT}=$ proteinkináz $\mathrm{B}(\mathrm{PBK}) ; \mathrm{AML}=$ akut myeloid leukaemia; $\mathrm{C} 3 \mathrm{~b}=$ complement receptor type $\mathrm{l} ; \mathrm{CD}=$ cluster of differentiation; CLL = krónikus lymphoid leukaemia; CXCR4 = kemokinreceptor-4; EV = extracelluláris vesicula; FLT3 = Fms-like tirozinkináz-3; IGF-IR = insulin-like növekedési faktor receptor; ITD = internális tandem duplikáció; $\mathrm{MHC}=$ (major histo- compatibility complex) fó hisztokompatibilitási rendszer; miRNS = mikro-RNS; MMP9 = mátrixmetalloproteináz-9; mRNS = messenger RNS; MV = microvesicula; $\mathrm{NK}=$ (natural killer cell) természetes ölősejt; NKG2D = (natural killer group D) természetes ölősejt $\mathrm{D}$ csoport; $\mathrm{NPMl}=$ nucleophosmin 1 ; snRNS $=$ (small nuclear RNS) kis sejtmagi RNS; TGF- $\beta=$ transzformáló növekedési faktor $\beta$ 
Az extracelluláris vesiculák (EV) mind eukaryoták, mind pedig prokaryoták esetén megfigyelhető, membránnal körülvett képletek, amelyek mérete 50-80 nm-tól több mikronig terjed [1]. A reticulocytaeredetú multivesicularis testek az extracelluláris térbe való kiürülésének leírása több mint 30 évvel ezelőttre tehető, két egymástól független kutatócsoporttól $[2,3]$. Az egyik csoport patkányokon folytatott kutatást, ahol a transzferrint, illetve transzferrinreceptor endocytosisát és intracelluláris termelődését vizsgálták [2], míg a másik csoport a juhok reticulocytáinak érése során vizsgálta a transzferrinreceptorokat [3]. Úgy gondolták, hogy ezeknek a vesiculáknak valódi biológiai jelentôségük nincs, úgynevezett „membránszemetek” (debris). Később, 1996-ban azonban leírták az adaptív immunválasz kiváltásában játszott szerepüket [4]. Ezek után intenzív kutatás témájává vált pontos biológiai funkcióik részletes feltérképezése, az EVpedia nemzetközi adatbázisa jelenleg 6879 publikációt tart számon az adott témakörben (http://www.evpedia.info/ 2016. május 3-án).

Elnevezésük még nem teljesen egységes a szakirodalomban. Méretük és keletkezési mechanizmusuk alapján azonban az alábbi három legszélesebb körben jellemzett csoport különíthető el: exosomák, microvesiculák és apoptotikus testek (1. táblázat) $[1,5,6]$.

Az exosoma elnevezés $d r$. Rose Johnstone nevéhez kapcsolódik [7]. Átmérőjük $100 \mathrm{~nm}$ körüli, amely átfed a vírusok méretével. Kettős foszfolipidréteg veszi körül óket, a multivesicularis testek exocytosisával keletkeznek. Főleg immunsejtek és tumorok esetén vizsgálták őket, egyik legkiemelkedőbb szerepük a sejtmentes antigénbemutatás $[1,5]$. A microvesiculák mérete 100-1000 nm-re tehetô, amely a baktériumok méretével mutat hasonlóságot [5]. A plazmamembránból füződnek le (blebbing), legjobban jellemzett forrásaik a vérlemezkék, a vörösvértestek és az endothelsejtek [1]. Az apoptotikus testek mérete $>1 \mu \mathrm{m}$, a programozott sejthalál kapcsán

1. táblázat $\mid$ Az extracelluláris vesiculák felosztása és legfontosabb jellemzőik [6]

\begin{tabular}{|c|c|c|c|}
\hline & Exosoma & Microvesicula & Apoptotikus test \\
\hline Méret & $\begin{array}{l}50-100 \mathrm{~nm} \\
\text { ( vírus) }\end{array}$ & $\begin{array}{l}100-1000 \mathrm{~nm} \\
(\sim \text { baktérium })\end{array}$ & $\begin{array}{l}1 \mu \mathrm{m} \\
\text { ( vérlemezke) }\end{array}$ \\
\hline Keletkezés & $\begin{array}{l}\text { Multivesicularis } \\
\text { testek exocytosisa }\end{array}$ & $\begin{array}{l}\text { Sejthártya- } \\
\text { blebbing }\end{array}$ & $\begin{array}{l}\text { Apoptózis } \\
\text { során }\end{array}$ \\
\hline $\begin{array}{l}\text { Legjobban } \\
\text { jellemzett } \\
\text { forrás }\end{array}$ & $\begin{array}{l}\text { Immunsejtek, } \\
\text { tumorok }\end{array}$ & $\begin{array}{l}\text { Vérlemezkék, } \\
\text { vörösvértestek, } \\
\text { endothelsejtek }\end{array}$ & $\begin{array}{l}\text { Programozott } \\
\text { sejthalál }\end{array}$ \\
\hline Tartalom & $\begin{array}{l}\text { Protein, lipid, } \\
\text { mRNS, miRNS, } \\
\text { DNS, } \\
\text { hösokkfehérjék, } \\
\text { enzimek, } \\
\text { MHC-receptor, } \\
\text { tetraspaninok, } \\
\text { membrán- } \\
\text { transzport-fehérjék }\end{array}$ & $\begin{array}{l}\text { Protein, lipid, } \\
\text { mRNS, miRNS, } \\
\text { snRNS }\end{array}$ & $\begin{array}{l}\text { Protein, lipid, } \\
\text { RNS, DNS }\end{array}$ \\
\hline
\end{tabular}

keletkeznek [8]. Szerepet játszhatnak többek között az onkogének horizontális transzferében [9]. Jellemzően kimutathatók az annexin-V-kötődés alapján [10].

Tekintettel arra, hogy az extracelluláris vesiculák igen nagyfokú heterogenitást mutatnak, az „extracelluláris vesicula" elnevezés használata tekinthető a legegyértelmúbbnek és legbiztonságosabban használhatónak mindaddig, amíg az egyes vesicula-alpopulációkra vonatkozóan nem rendelkezünk specifikus molekuláris markerekkel.

Többek közt a sejtek közötti kommunikációban, az angiogenezisben, az intracelluláris komponensek eltávolításában, a szervezet immunválaszában és a véralvadásban is megfigyelték ôket (1. ábra) [11].

Az extracelluláris vesiculák múködése lehetôvé teszi a fehérjék, RNS-, ső́t DNS-sejtek közötti kicserélődését [11]. Fiziológiás esetben a sejt felesleges anyagainak elszállításában igen fontosak lehetnek. A sejtek által vesiculákba csomagolt molekulák ugyanis endocytosis útján kerülnek eltávolításra a keringésből. Patológiás esetben azonban ez a folyamat feltehetően nem megfelelően múködik, így a csökkent endocytosis szerepet játszhat például daganatos kórképek folyamataiban [12].

Extracelluláris vesiculákat mind az egészséges, mind a daganatos sejtek termelnek $[4,13]$. Izolálhatók vérből, cerebrospinalis folyadékból, synovialis folyadékból, nyirokból, vizeletből, hasúri folyadékból, anyatejből, nyálból, orrváladékból vagy akár könnyből is $[14,15]$. Yuana és mtsai számos tanulmány alapján arra a következtetésre jutottak, hogy a testfolyadékok jól elkülöníthetô vesiculaprofillal rendelkeznek [11].

A sejtek közötti kommunikációban betöltött funkciójuk feltérképezése érdekében vizsgálták az EV-k mikroRNS-tartalmát. A mikro-RNS-ek olyan nem kódoló RNS-ek, amelyek a gének szabályozása révén befolyásolják a sejtnövekedést, a szöveti differenciálódást, a sejtosztódást és az apoptózist is [16]. A tumoros sejtek által termelt exosomák mennyiségét és a bennük szállított mikro-RNS profilját vizsgálva a normális sejttől eltérő mikro-RNS-profilt találtak. Megfigyelték azt is, hogy különböző daganatos sejtek (emlő-, petefészek-, prosztata-, nyelőcső- és tüdőadenocarcinoma, melanoma, hepatocellularis carcinoma, metasztatikus gyomorrák) által termelt exosomák száma a vérben magasabb, összehasonlítva az egészségesekkel. A megnövekedett menynyiségú exosoma által lehetôség nyílik a tumorasszociált jelátviteli molekulák és mikro-RNS-ek célsejthez való eljutásának vizsgálatára, ami a daganatos állapotok progressziójában is valószínúsíti jelentőségüket [17].

\section{A legjellemzőbben alkalmazott vizsgálati módszerek extracellulárisvesicula- kutatásokban}

Az EV-vizsgálatokat illetően szerteágazó metodikai arzenállal találkozhatunk a nemzetközi szakirodalomban. A laboratóriumi módszerek terén újabb és újabb techni- 


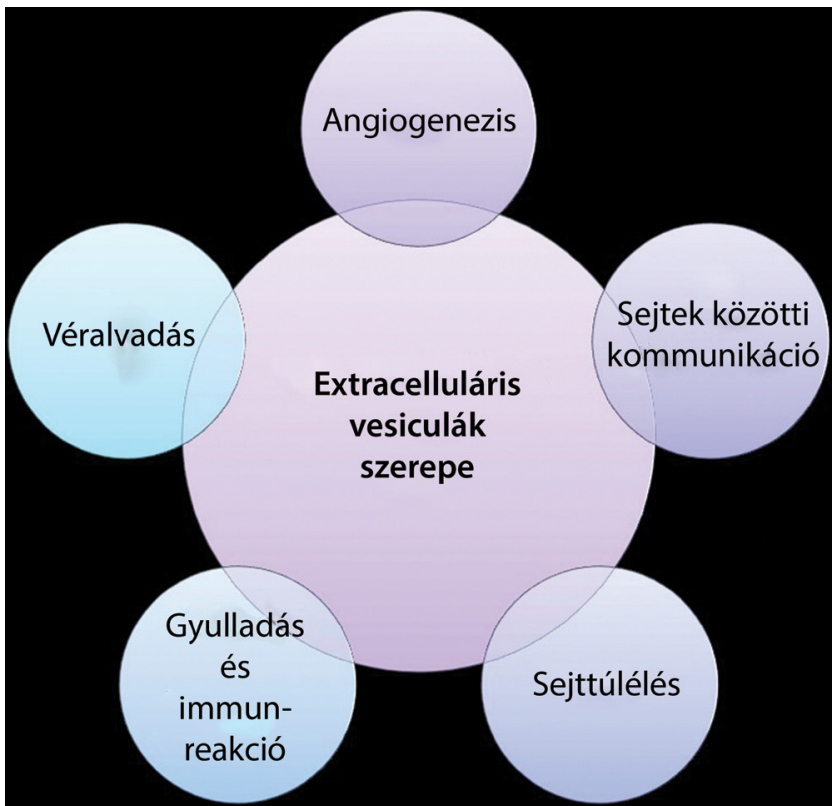

1. ábra $\quad$ Az extracelluláris vesiculák szerepe

kák látnak napvilágot, így nem meglepő, hogy az extracelluláris vesiculák izolálásának és karakterizálásának standardizációja jelenleg is folyik.

A teljesség igénye nélkül kiemelhető néhány módszer (2. ábra), amelyet az extracelluláris vesiculák vizsgálata során alkalmaztak: izolálásuk a legtöbb esetben differenciálcentrifugálással történt, az izolált vesiculák összetételét Western blot módszerrel, áramlási citometriával, fluoreszcenciás mikroszkópos vagy transzmissziós elektronmikroszkópos képalkotással, dinamikus fényszórásos spektroszkópiával, „nanoparticle tracking analysis” és „tunable resistive pulse sensing” módszerrel vizsgálták több kutatásban is [18-23].

\section{Az extracelluláris vesiculák szerepe a különböző patológiás kórképekben}

Az extracelluláris vesiculákat egészséges sejtek is termelik [4]. Azonban számos betegségben megfigyelhető, hogy a vesiculák száma vagy jellemzői megváltoznak, például autoimmun betegségekben, cardiovascularis kórképekben, szepszis, 2-es típusú cukorbetegség és tumorok esetén [1].

\section{Extracellulárisvesicula-kutatások hematológiai malignitásokban}

Az EV-k malignitásokban betöltött funkciójáról számos publikáció született, azonban ezek nagy része szolid tumoros kórképeket (például glioblastoma, medulloblastoma, melanoma) vizsgált $[14,21]$. Egészséges kontroll-

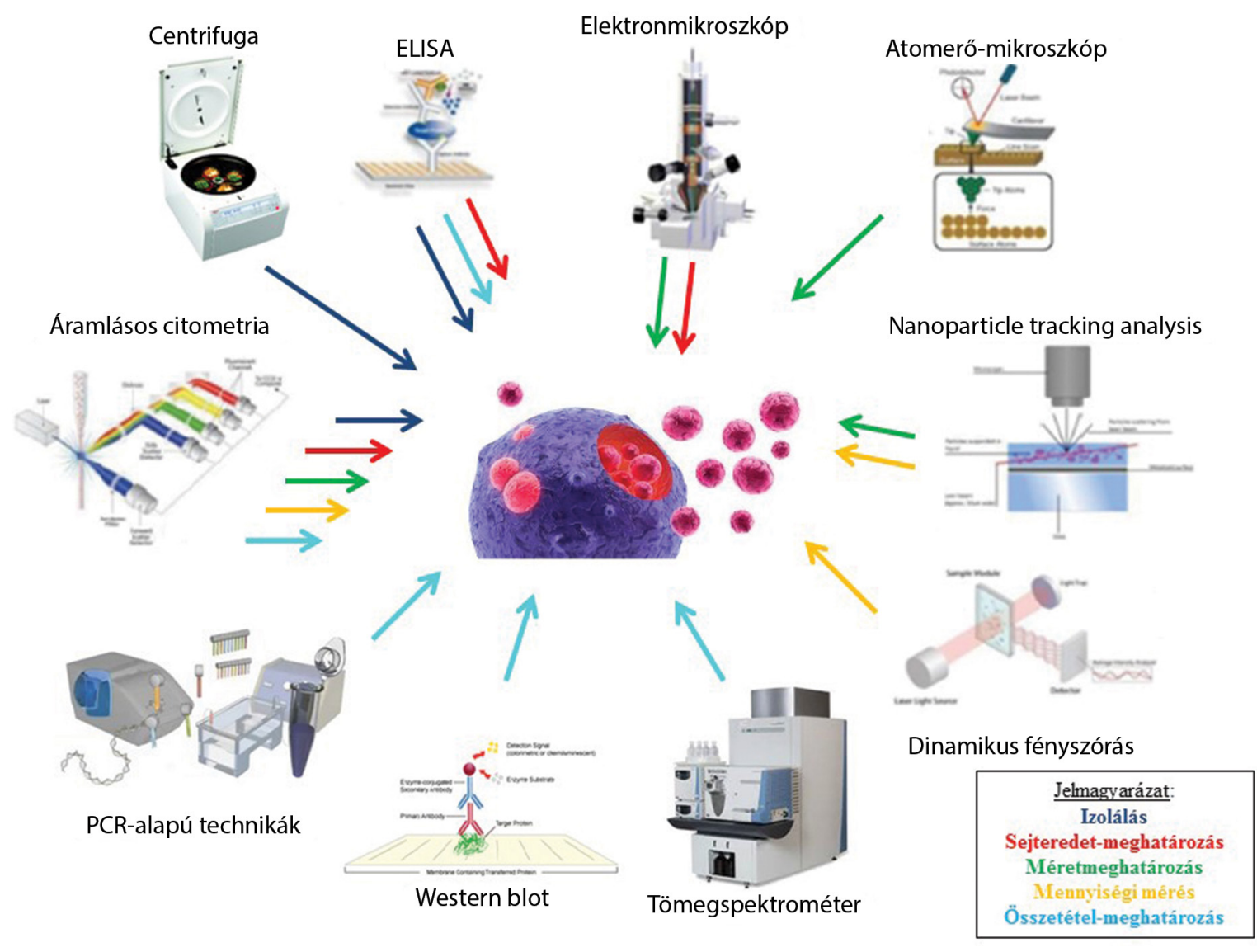

2. ábra $\quad$ Az extracellulárisvesicula-vizsgálatokban alkalmazott módszerek [23] 
csoportokkal összevetve több kutatásban is megfigyelték a szérumban mérhető vesiculák megnövekedett mennyiségét daganatos állapotok kapcsán (petefészektumor, tüdőadenocarcinoma) [24, 25]. Jóval kevesebb vizsgálat folyt hematológiai malignitások és az extracelluláris vesiculák kapcsolatára vonatkozóan [20, 26-29]. Ezeket mutatjuk be összefoglalónk hátralévő részében.

\section{Microvesicula-vizsgálat krónikus lymphoid leukaemiában}

Egészséges vérplazmában áramlási citometriával mérve a microvesiculák (MV-k) 80\%-a vérlemezke-eredetú, a maradék 10-10\% pedig leukocyta- és endotheliumeredetet mutat (az arányok jelentősen függnek az alkalmazott véralvadásgátló szertől). Ghosh és mtsai krónikus lymphoid leukaemiás (CLL) betegek vérplazmáját vizsgálva magasabb arányú vérlemezke-eredetû microvesicula(CD61+ MV) arányt írtak le [30]. Emellett a CD19+ MV-populációt is emelkedettnek találták előrehaladott CLL esetén (a CD19 antigén B-lymphocyta-eredetü). Valószínú, hogy a megfigyelt relatív magas CD19+ MV-k leukaemiás eredetűek [30].

További vizsgálatokkal bizonyították, hogy a plazmában lévő CLL-eredetű MV-k képesek kötődni a csontvelő stromalis sejtjeivel, majd internalizálódni, azoknak át tudják adni a tartalmukat, sőt akár az AKT jelátviteli útvonalat állandó aktivált állapotban képesek tartani a csontvelő stromasejtjeiben [30].

A gyógyszer-rezisztencia kialakulásában is felmerült az MV-k szerepe. Ismert, hogy emelkedett szolúbilis CD52 és CD20 antigénszintek figyelhetők meg CLL-es betegek vérplazmájában. Kimutatták, hogy a CD52 molekulák kötődtek a CLL-es MV-khez, és ezeknek a szintje emelkedett a betegség rosszabbodásával. Valószínú, hogy a CD20 és CD52 molekulák többnyire microvesiculák által kötve vannak jelen. Lehetséges, hogy a keringésben akkumulálódó MV-k CLL-ben lekötik a specifikus ellenanyagokat, és ezáltal szerepük lehet az anti-CD52 alemtuzumab és az anti-CD20 rituximab elleni rezisztencia kialakulásában [30].

\section{Akut myeloid leukaemia és a vesiculák immunmoduláló szerepe}

A szakirodalomban ismert, hogy akut myeloid leukaemiás betegekben (AML) alacsony a természetes ölősejtek (NK) citolitikus aktivitása $[18,28]$. Egyes vizsgálatok arra utalnak, hogy blasteredetû microvesiculák által közvetített mechanizmusok állhatnak a jelenség hátterében. Ezek a microvesiculák a TGF- $\beta 1$ útvonalon keresztül downregulálják az NKG2D-aktiváló receptor expresszióját és ezzel gátolják az NK-sejtek aktivitását. Ez a mechanizmus az immunrendszer elól való menekülésben segítheti a malignus sejteket [18]. Ez a publikáció írta le először AML-ben a szérumban lévő microvesiculák le- hetséges szerepét az NK-sejtek aktivitásának szabályozásában, míg szolid tumoroknál már régebben is folytattak ez irányú kutatásokat $[31,32]$.

\section{Extracelluláris vesiculák $A M L-b e n$, mint potenciális biomarkerek}

AML-sejtvonalak és primer AML-es sejtek által ex vivo termelt exosomákat vizsgáltak egy nemrég publikált tanulmány szerzői. Ezen exosomákban ki tudták mutatni számos ismert, a leukemogenesisben, prognosztikában (FLT3-ITD, NPMl), csontvelői niche szabályozásában (IGF-IR, CXCR4, MMP9), kezelési targetként (FLT3-ITD, IGF-IR, CXCR4) szerepet játszó gén mRNS-ét, illetve az AML patogenezisében korábbról ismert nem kódoló RNS-eket. A blastokkal együtt tenyésztett niche jellegű sejtek felvették a vizsgált exosomákat, és kimutathatóan megváltoztatták azok növekedésifaktor-termelését. Ezek az eredmények arra utalnak, hogy a leukaemiás sejtek vesiculák révén befolyásolják, alakítják a csontvelői környezetüket [20, 33-35].

Hornick és mtsai xenograftmodellt alkalmaztak kutatásukhoz, amelynek alapján exosomalis miRNS-t javasolnak AML-ben a minimális residualis betegség biomarkerének [36]. Az utóbbi években publikáltak humán megfigyeléseket is. Ezek szerint leukaemiás, lymphomás betegek vérében emelkedik az extracelluláris vesiculák mennyisége, és minőségi változások is megfigyelhetők az egészségesek véréből nyert vesiculákkal összehasonlítva. A betegek vesiculáinak felszínén számos olyan, áramlási citometriával követhető marker megtalálható, amely az adott betegségben jellemző malignus sejtek diagnosztikájában rutinszerúen használatos (például AML-ben microvesiculákon $\mathrm{CD} 13, \mathrm{CD} 33, \mathrm{CD} 34, \mathrm{CD} 117$, exosomákon CD34, CD105, CD200 markerek). A vesiculák mennyisége, egyes hordozott markerek korreláltak az adott malignitás ismert prognosztikus faktoraival. Egy tanulmányban a blastmarkert hordozó, ez alapján szeparált exosomák fehérjemintázatát vizsgálták, és hasonlónak találták az őket kibocsátó leukaemiás sejtek fehérjemintázatához. Diagnóziskor és a kezelés egyes szakaszai során, majd a kezelés végén AML-es betegek véréből nyert exosomák fehérjemintázata jellegzetes különbségeket mutatott. E közlemények felvetik, hogy az extracelluláris vesiculákat biomarkerként hasznosíthatnánk hematológiai malignitások diagnosztikájában, a maradék betegség követésére [18, 26, 29, 37]. A vér vagy a vizelet vesiculáinak vizsgálata lényegesen kevésbé invazív mintavételt igényelne, mint sok más, jelenleg rutin-vizsgálóeljárás.

\section{Következtetések}

Az extracelluláris vesiculákkal kapcsolatos kutatások nagy száma ellenére azok szerepe, múködése még messze nem ismert teljesen. A szervezet homeosztázisának fenntar- 
tásában és a sejtek közötti kommunikációban egyértelmúen részt vesznek. Az emberi szervezet minden testnedvében megtalálhatók, a csoportosításukra és kimutatásukra vonatkozó ajánlások jelenleg dinamikusan fejlődnek. Számos kórképben figyelték meg az extracelluláris vesiculák megváltozott számát és/vagy tartalmát, ez indokolja a további vizsgálatokat. Malignus hematológiai kórképeknél a patomechanizmusban (mikrokörnyezet kialakítása, leukaemia elleni immunválasz elnyomása), a prognosztikában, a gyógyszer-rezisztencia kialakulásában és a betegség követésében is felvetődött a vesiculák szerepe. Az eddigi eredmények azzal kecsegtetnek, hogy az extracelluláris vesiculákban értékes biomarkereket lelhetünk.

Anyagi támogatás: A közlemény megírása a Nemzeti Kutatási, Fejlesztési és Innovációs Hivatal - NKFIH, K115861 pályázatból anyagi támogatásban részesült.

Szerzői munkamegosztás: R. A.: Az első teljes verzió megírása, javítások beépítése. K. N.: Vesiculák vizsgálómódszereiről szóló részek és az ábrák elkészítése. Cs. S. J.: Vesiculák fiziológiás szerepéről szóló részek. K. A.: Vesiculák összetételéről szóló részek. P. K.: Bevezető. F. S. Á., B. E.: Szenior ellenőrzés és kiegészítés. E. D. J.: A közlemény felépítésének tervezése, a leukaemiákról szóló részek. A cikk végleges változatát valamennyi szerző elolvasta és jóváhagyta.

Érdekeltségek: A szerzőknek nincsenek érdekeltségeik.

\section{Irodalom}

[1] György, B., Szabó, T. G., Pásztói, M., et al.: Membrane vesicles, current state-of-the-art: emerging role of extracellular vesicles. Cell. Mol. Life Sci., 2011, 68(16), 2667-2688.

[2] Harding, C., Heuser, J., Stabl, P.: Endocytosis and intracellular processing of transferrin and colloidal gold-transferrin in rat reticulocytes: demonstration of a pathway for receptor shedding. Eur. J. Cell Biol., 1984, 35(2), 256-263.

[3] Pan, B. T., Johnstone, R. M.: Fate of the transferrin receptor during maturation of sheep reticulocytes in vitro: selective externalization of the receptor. Cell, 1983, 33(3), 967-978.

[4] Raposo, G., Nijman, H. W., Stoorvogel, W., et al.: B lymphocytes secrete antigen-presenting vesicles. J. Exp. Med., 1996, 183(3), 1161-1172.

[5] Théry, C., Ostrowski, M., Segura, E.: Membrane vesicles as conveyors of immune responses. Nat. Rev. Immunol., 2009, 9(8), 581-593.

[6] Kalra, H., Simpson, R. J., Ji, H., et al.: Vesiclepedia: a compendium for extracellular vesicles with continuous community annotation. PLoS Biol., 2012, 10(12), el001450.

[7] Johnstone, R. M., Adam, M., Hammond, J. R., et al.: Vesicle formation during reticulocyte maturation. Association of plasma membrane activities with released vesicles (exosomes). J. Biol. Chem., 1987, 262(19), 9412-9420.

[8] Hristov, M., Erl, W., Linder, S., et al.: Apoptotic bodies from endothelial cells enhance the number and initiate the differentiation of human endothelial progenitor cells in vitro. Blood, 2004, 104(9), 2761-2766.
[9] Bergsmedh, A., Szeles, A., Henriksson, M., et al.: Horizontal transfer of oncogenes by uptake of apoptotic bodies. Proc. Nat. Acad. Sci. U.S.A., 2001, 98(11), 6407-6411.

[10] Van Engeland, M., Nieland, L. J., Ramaekers, F. C., et al.: Annexin V-affinity assay: a review on an apoptosis detection system based on phosphatidylserine exposure. Cytometry, 1998, 31(1), $1-9$.

[11] Yuana, Y., Sturk, A., Nieuwland, R.: Extracellular vesicles in physiological and pathological conditions. Blood Rev., 2013, 27(1), 31-39.

[12] Böing, A. N., Hau, C. M., Sturk, A., et al.: Platelet microparticles contain active caspase 3. Platelets, 2008, 19(2), 96-103.

[13] Valadi, H., Ekström, K., Bossios, A., et al.: Exosome-mediated transfer of mRNAs and microRNAs is a novel mechanism of genetic exchange between cells. Nat. Cell Biol., 2007, 9(6), 654659.

[14] Akers, J. C., Gonda, D., Kim, R., et al.: Biogenesis of extracellular vesicles (EV): exosomes, microvesicles, retrovirus-like vesicles, and apoptotic bodies. J. Neurooncol., 2013, 113(1), 1-11.

[15] Van der Pol, E., Böing, A. N., Harrison, P., et al.: Classification, functions, and clinical relevance of extracellular vesicles. Pharmacol. Rev., 2012, 64(3), 676-705.

[16] Esquela-Kerscher, A., Slack, F. J.: Oncomirs - microRNAs with a role in cancer. Nat. Rev. Cancer, 2006, 6(4), 259-269.

[17] Hannafon, B. N., Ding, W. Q.: Intercellular communication by exosome-derived microRNAs in cancer. Int. J. Mol. Sci., 2013, 14(7), 14240-14269.

[18] Szczepanski, M. J., Szajnik, M., Welsh, A., et al.: Blast-derived microvesicles in sera from patients with acute myeloid leukemia suppress natural killer cell function via membrane-associated transforming growth factor-betal. Haematologica, 2011, 96(9), 1302-1309.

[19] Clayton, A., Court, J., Navabi, H., et al.: Analysis of antigen presenting cell derived exosomes, based on immuno-magnetic isolation and flow cytometry. J. Immunol. Methods, 2001, 247(1-2), 163-174.

[20] Huan, J., Hornick, N. I., Shurtleff, M. J., et al.: RNA trafficking by acute myelogenous leukemia exosomes. Cancer Res., 2013, 73(2), 918-929.

[21] Wojtuszkiewicz, A., Schuurbuis, G. J., Kessler, F. L., et al.: Exosomes secreted by apoptosis-resistant acute myeloid leukemia (AML) blasts harbor regulatory network proteins potentially involved in antagonism of apoptosis. Mol. Cell. Proteomics, 2016, 15(4), 1281-1298.

[22] Dragovic, R. A., Gardiner, C., Brooks, A. S., et al.: Sizing and phenotyping of cellular vesicles using Nanoparticle Tracking Analysis. Nanomedicine, 2011, 7(6), 780-788.

[23] Tissot, J. D., Canellini, G., Rubin, O., et al.: Blood microvesicles: From proteomics to physiology. Translat. Proteomics, 2013, $1(1), 38-52$.

[24] Taylor, D. D., Gercel-Taylor, C.: MicroRNA signatures of tumorderived exosomes as diagnostic biomarkers of ovarian cancer. Gynecol. Oncol., 2008, 110(1), 13-21.

[25] Rabinowits, G., Gerçel-Taylor, C., Day, J. M., et al.: Exosomal microRNA: a diagnostic marker for lung cancer. Clin. Lung Cancer, 2009, 10(1), 42-46.

[26] Hong, C. S., Muller, L., Boyiadzis, M., et al.: Isolation and characterization of CD34+ blast-derived exosomes in acute myeloid leukemia. PLoS ONE, 2014, 9(8), el03310.

[27] Abaron, A., Rebibo-Sabbah, A., Tzoran, I., et al.: Extracellular vesicles in hematological disorders. Rambam Maimonides Med. J., 2014, 5(4), e0032.

[28] Szczepanski, M. J., Szajnik, M., Welsh, A., et al.: Interleukin-15 enhances natural killer cell cytotoxicity in patients with acute myeloid leukemia by upregulating the activating NK cell receptors. Cancer Immunol. Immunother., 2010, 59(1), 73-79.

[29] Caivano, A., Laurenzana, I., De Luca, L., et al.: High serum levels of extracellular vesicles expressing malignancy-related markers 
are released in patients with various types of hematological neoplastic disorders. Tumour Biol., 2015, 36(12), 9739-9752.

[30] Ghosh, A. K., Secreto, C. R., Knox, T. R., et al.: Circulating microvesicles in B-cell chronic lymphocytic leukemia can stimulate marrow stromal cells: implications for disease progression. Blood, 2010, 115(9), 1755-1764.

[31] Bergmann, C., Strauss, L., Wieckowski, E., et al.: Tumor-derived microvesicles in sera of patients with head and neck cancer and their role in tumor progression. Head Neck, 2009, 31(3), 371380.

[32] Valenti, R., Huber, V., Iero, M., et al.: Tumor-released microvesicles as vehicles of immunosuppression. Cancer Res., 2007, 67(7), 2912-2915

[33] Bacher, U., Schnittger, S., Haferlach, T.: Molecular genetics in acute myeloid leukemia. Curr. Opin. Oncol., 2010, 22(6), 646655.

[34] Chapuis, N., Tamburini, J., Cornillet-Lefebvre, P., et al.: Autocrine IGF-1/IGF-1R signaling is responsible for constitutive
PI3K/Akt activation in acute myeloid leukemia: therapeutic value of neutralizing anti-IGF-1R antibody. Haematologica, 2010, 95(3), 415-423.

[35] Olsnes, A. M., Hatfield, K. J., Bruserud, Ø.: The chemokine system and its contribution to leukemogenesis and treatment responsiveness in patients with acute myeloid leukemia. J. Balkan Union Oncol., 2009, 14(Suppl. 1), S131-S140.

[36] Hornick, N. I., Huan, J., Doron, B., et al.: Serum exosome microRNA as a minimally-invasive early biomarker of AML. Sci. Rep., 2015, 5, 11295.

[37] Hong, C. S., Muller, L., Whiteside, T. L., et al.: Plasma exosomes as markers of therapeutic response in patients with acute myeloid leukemia. Front. Immunol., 2014, 5, 160.

(Erdélyi Dániel János dr., Budapest, Tüzoltó utca 7-9., 1094 e-mail: erdelyi.daniel@med.semmelweis-univ.hu)

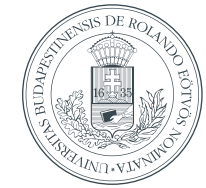

ELTE 矛 ÁJK

JOGI TOVÁBBKÉPZÓ INTÉZET

\section{LEGYEN A HALLGATÓNK!}

\section{Szakirányú egyetemi (föiskolai) oklevéllel záruló posztgraduális képzéseink}

\section{Jogászoknak:}

Adójogi szakjogász

Adatbiztonsági és adatvédelmi szakjogász

Befektetési, vállalatfinanszirozási,

tözsdei szakjogász

Biztositási szakjogász

Családjogi szakjogász

Egészségügyi szakjogász

European Human Rights (angol nyelven)

Gazdasági büntetöjogi szakjogász

Környezetvédelmi szakjogász

Közbeszerzési szakjogász

Munkajogi szakjogász

Társasági jogi és cégjogi szakjogász

Jogi szakvizsga elókészito"
Nem jogászoknak:

Adatbiztonsági és adatvédelmi jogi

szakokleveles szakember

Jogi szakokleveles gazdasági szakember

Jogi szakokleveles környezetvédelmi szakember

Jogi szakokleveles orvos és egészségügyi szakember

Munkajogi szakokleveles tanácsadó

www.ajk.elte.hu/jotoki

www.eltejti.hu

eltejti@ajk.elte.hu

Munkanapokon 8-16 óra között hivható telefonszámaink: +3613185912és +3612662563 